\title{
Effect of Envy and Altruism on Conspicuous Consumption Orientation: A Research in Kırıkkale, Turkey
}

İbrahim BOZACI (https://orcid.org/0000-0002-9584-6126), Department of Marketing, Kurlkkale University, Turkey; e-mail: iborganizer@gmail.com

\section{Haset ve Özgeciliğin Gösteriş Odakı Tüketime Etkisi: Kırıkkale’de Bir Araştırma}

\begin{abstract}
In this research, effect of envy on conspicuous consumption and moderating role of altruism was examined. Within the scope of the research, primary data were collected by convenience sampling method in the Kirıkkale province of Turkey. After performing confirmatory factor analyses, structural equation models were tested over the gathered data with the statistical package program IBM AMOS. According to the findings, the hypotheses of benign envy, malicious envy, and altruism being the possible factors affecting conspicuous consumption were supported. Besides, the moderating role of altruistic personality on the effect of malicious envy on conspicuous consumption has been determined. Finally, several suggestions were developed for firms and researchers based on interpreting the research findings.

Keywords

: Envy, Malicious Envy, Benign Envy, Altruism, Conspicuous Consumption Orientation.

JEL Classification Codes : D12, D91, P36.

\section{$\ddot{\mathbf{O} z}$}

$\mathrm{Bu}$ araştırmada, hasedin gösteriş odaklı tüketime etkisi ve bu etkide özgeciliğin düzenleyici rolü incelenmektedir. Araştırma kapsamında Kırıkkale İlinde kolayda örnekleme yöntemiyle birincil veri toplanmıştır. Elde edilen veriler IBM AMOS adlı istatistiksel paket programıyla analiz edilmiş, bu kapsamda doğrulayıcı faktör analizleri gerçekleştirilmiş ve yapısal eşitlik modelleri test edilmiştir. Araştırma bulgularına göre, zararlı haset, zararsız haset ve özgeciliğin gösteriş tüketimini etkileyen faktörler olduğu iddiaları desteklenmiştir. Ayrıca, özgeci kişisel özelliğin zararlı hasedin gösteriş odaklı tüketim üzerindeki etkisinde düzenleyici rolü tespit edilmiştir. Son olarak araştırma bulguları yorumlanmış ve işletme ve araştırmacılar için öneriler geliştirilmiştir.
\end{abstract}

Anahtar Sözcükler $\quad$ : Haset, Zararlı Haset, Zararsız Haset, Özgecilik, Gösteriş Odaklı Tüketim. 
Bozac1, İ. (2021), "Effect of Envy and Altruism on Conspicuous Consumption

Orientation: A Research in Kırıkkale, Turkey", Sosyoekonomi, 29(48), 75-89.

\section{Introduction}

It is known that the well-being of people is influenced by perceptions about the wellbeing of others (Zizzo, 2003) and consumers frequently compare themselves with other consumers (Pancer \& Ashworth, 2009). With the increase in industrialization and subsequent (18th century) income and the emergence of a strong middle socioeconomic class, consumers increased who shows their consumption to others (Page, 1992). In this context, conspicuous consumption can be characterized social dimension of consumer behaviour which takes attention of in the field of consumer behaviours. Moreover, despite the recent increase in research on the role of emotions in decision making and behaviour, there are few studies on the effect of envy in consumer behaviour, especially for conspicuous consumption. In short, as an emotion felt by everyone, it is inevitable to affect consumers behaviours, especially in terms of socially visible ones.

At this point, although the feeling of envy has been studied for a long time in philosophy, sociology, economics, psychology, organizational behaviour and religion research fields (Stevens, 1948; Foster et al., 1972; Feldman \& Kirman, 1974; Parrott \& Smith, 1993), consumer behaviour researchers has recently give attention to the subject. While reference groups, fashion product preferences, word of mouth communication and interpersonal influence are areas of research in which the role of others in consumer behaviour is widely studied, the effects of envy have been newly discussed. Moving from the idea that it is possible to accelerate the desire to jump social class through consumption, especially by the sense of envy (Belk, 2011), this study examines the effect of envy on conspicuous consumption and the moderating role of altruism on this relationship.

People can feel uncomfortable or bad with what others have and this situation may be a motivation factor for consumption behaviour especially for conspicuous consumption. At this point, it is thought that conspicuous consumption, which refers to conveying messages with the purchased products to others, is closely related to the feeling of envy. On the other hand, it is discussed in this research altruism, which is focusing more on the benefits of others rather than individual's own interests, can negatively affect the conspicuous consumption. It is tried to be answered in the scope of the research; how the conspicuous consumption will be shaped by altruism and envy.

\section{Conceptual Framework}

\subsection{Envy and the Role of Envy in Consumer Behaviour}

Envy, which is a feeling that arises when a person does not have superior assets or achievements that others have (Parrott \& Smith, 1993); is a negative emotion that exists in everyone (Foster et al., 1972) and especially in the face of things we haven't. The feeling of envy, which is different from the feeling of jealousy, is about the things that others have or can do, but the jealousy is related to things that we have (Belk, 2011: 121).

The feeling of envy is explained in two types: malicious envy and benign envy (Lange $\&$ Crusius, 2015). While malicious envy causes efforts to withdraw the other side against 
the negative situation of the individual (Gershman, 2014), benign envy causes efforts to decrease negative feelings. Although the envy is considered as a negative emotion that generally negatively affects welfare and life satisfaction (Belk, 1985; Cohen-Charash, 2009), especially benign envy is expressed as positive dimension of envy and it can motivate human behaviour (Cirpan \& Özdoğru, 2017).

Although envy is widely researched in the field of psychology as an emotion encountered in life, it has received relatively little attention as an emotion related with consumption. However, consumers want to have what others have and can motivate consumption depending on this situation (Morgan-Knapp, 2014; Leibenstein, 1950). At this point, the sense of envy in the context of consumption can be caused by the desired products or purchasing behaviours of others (Ackerman \& Perner, 2004; Crusius \& Mussweiler, 2012). Belk (1984) considered the envy in the context of consumption as a component of materialism and an emotion felt for the assets that others have. In current researches, it is accepted that materialism is seeing material assets in the centre of life, success and happiness, and the feeling of envy may be the emotional and behavioural indicator of materialism (Podoshen \& Andrzejewski, 2012). Indeed, Richins \& Dawson (1992), who consider materialism as cognitive values, explain materialism as seeing material assets at the centre of life as the basis of success and happiness. In short, materialism is different from the concept of envy. Because it is possible for the individual to place his assets in a central position of life without feeling uncomfortable about others have or without trying to prevent them.

\subsection{Conspicuous Consumption}

Conspicuous consumption; which is carried out in order to reach the social class that the individual desires or to differentiate from the lower classes and imitates the consumption patterns of the desired upper class (Tosun \& Cesur, 2018), is based primarily on Veblen's the Theory of the Leisure Class. Accordingly, wealthy Americans spend significant portion of their time and money on social class-based preferences unnecessarily and inefficiently (Mason, 2001). Today, the understanding of consumers can buy brands to show their presence to others (Amaldoss \& Jain, 2005), can use them as a symbol of prestige, try to attract the attention of others and want to influence others through them, is accepted (Truong et al., 2008).

It is possible that conspicuous consumption occurs in ways such as displaying assets to others and gaining social status in this way (Veblen effect), showing that they belong to a particular social group (Bandwagon effect) and they are different from others by making rare choices (Snob effect) (Leibenstein, 1950). The common point of these views explaining conspicuous consumption as; it occurs depending on the existence of others, one's thoughts about what others think and take place in order to give messages to others.

Conspicuous consumption is affected by many factors. Materialism (Fournier \& Richins, 1991; Richins, 1994; Wong, 1997; O’Cass, 2001; Fitzmaurice \& Comegys, 2006; Podoshen \& Andrzejewski, 2012), use of social media like facebook (Taylor \& Strutton, 
2016; Thoumrungroje, 2014), peer communication (Balikcioglu \& Volkan, 2016), gender (especially in women in clothing products) (O'Cass, 2001; Segal \& Podoshen, 2013), ethnic characteristics (Podoshen et al., 2011, Podoshen et al., 2014) are some of these factors. In this study, relationships among the feeling of envy, the altruism and conspicuous consumption is examined.

\section{Hypothesis Development}

In this part of the study, the possible relationships among the research variables are investigated theoretically, namely effects of envy and altruism on conspicuous consumption.

\subsection{Envy and Conspicuous Consumption}

It is possible that the feeling of envy can cause to acquire assets in order to access better positions of others (Christen \& Morgan, 2005; Feinberg et al., 2002). Researches shows that especially benign envy can cause consumers to compete with others in terms of having more attractive advantages, to consume the products they consume (cars, clothes, telephones, travel, etc.) (Belk, 2011). Expensive and luxury assets that people compare with others and inability to access them easily can cause feeling of envy. The high-level feeling of envy is associated with giving more value to expensive products and conveying messages to others (Wong \& Ahuvia, 1998).

As a matter of fact, in Le's (2015) research, it was concluded that the envy caused conspicuous consumption. Similarly, Taylor and Strutton (2016) showed that the feeling of envy caused the individual to have more desire to consume conspicuously on social media. In the experimental study of Ahn et al. (2018), it was found that especially benign envy caused more desire to buy economic capital related products such as luxury clothes. Moreover Belk (2008) concluded that benign envy can cause people to make sacrifices for luxury products, even from necessary products. As a result, it is understood that the conspicuous consumption can be affected by envy and the two hypotheses of the research are formed as follows:

H1: Benign envy affects conspicuous consumption.

H2: Malicious envy affects conspicuous consumption.

\subsection{Altruism and Conspicuous Consumption}

Altruistic behaviour is expressed as; the desire to act in solidarity towards the benefit of other people (Lay \& Hoppmann, 2015), the behaviour shown to the benefit of other organisms before the benefit of the organism that acts. A person, who was saved by someone when he/she about to drown, encountered an altruistic behaviour (Trivers, 1971). While altruism encourages solidarity behaviours, selfishness prevents these (Fehr \& Fischbacher, 2003).

Becker (1976) states that altruism increases the desire to decrease one's own consumption to increase the consumption of others. Altruism, which causes behaving in 
favour of other people (especially for close family members) (Mujcic \& Frijters, 2015), is an important variable of social life and may lead to consumption behaviours (voluntary tourism, etc.) in favour of others. Thus, it is possible for people to behave based on more abstract collaborative motives beyond their basic needs due to altruism (Mustonen, 2007).

Altruism is more common in collaborative cultures as it relates to the importance given to solidarity with others. On the other hand, individualism is related to giving more importance to self and less willing to sacrifice for others of the group they are a part of (Hofstede \& Bond, 1984). The individualistic personality feature causes the person to invest more in his own identity and to send messages with assets they own (Wong \& Ahuvia, 1998). At this point, it is seen that conspicuous consumption is higher in countries with individualist culture (Souiden et al., 2011; Browne \& Kaldenberg, 1997). On the other hand, collaborative people attach importance to developing good relations with the group or society they belong to (Wong \& Ahuvia, 1998).

In this research, instead of the effect of individualistic/collectivistic cultural value on conspicuous consumption, the effect of altruism on conspicuous consumption is examined since the effect of the collectivism on conspicuous consumption is not clear. Moreover, although there are studies showing that high individualism is related with increasing in conspicuous consumption (Sun et al., 2004) and the increase in income in collective social contexts decreases conspicuous consumption (Ordabayeva \& Chandon, 2010); researches show that consumers in collective culture can attach more importance to the relations with others (Triandis, 1989), can see conspicuous consumption as an acceptable behaviour (Piron, 2000) and can consume to give messages to others, especially due to the high level of materialism (Teimourpour \& Heidarzadeh, 2011; Mai \& Tambyah, 2011; Awanis et al., 2017).

It is asserted in Adler's Individual Psychology Theory, the need to experience a sense of social interest and belonging, increases human well-being or altruistic behaviour (Tan, 2019; Ferguson, 1989; Clark, 1985; Shon \& Barton-Bellessa, 2015). At this point; altruism is generally examined in terms of its relationship with inheritance (Lord \& Rangazas, 1991), engaging in solidarity behaviours (Luo et al., 2007; Lamberton, 2016; Hartl et al., 2016; Bucher et al., 2016), sharing lecture notes with friends, being helpful in daily friend relationships, supporting activities related to the disabled, buying unleaded gasoline, donating blood (Schwartz, 1977), donating organ (Shaw, 2010; Mongoven, 2003; Sque et al., 2006; Horton, 1991; Horton \& Horton, 1991; Kopfman \& Smith, 1996), gift giving (de Peyrelongue et al., 2017; Taylor et al., 2012), consuming organic products (Yaday, 2016) and giving importance to healthy product consumption (Simunaniemi et al., 2013). But as a result of desire to help others and to reduce the dilemmas caused by the conspicuous consumption (Posner, 1997), altruism, which encourages socially beneficial consumption behaviours, can reduce conspicuous consumption due to the fact that buying expensive and luxurious products can prevent consumers from acting altruist due to reduction in resources. In addition to these, considering the assumption that altruism contradicts with the conspicuous consumption, the moderator role of the altruism in the effect of envy is 
questioned within the scope of the research. In short, the following hypothesis of the research is constructed:

H3: Altruism affects conspicuous consumption.

H4: Altruism plays moderating role in the effect of malicious envy on conspicuous consumption.

H5: Altruism plays moderating role in the effect of benign envy on conspicuous consumption.

As understood in the marketing literature about conspicuous consumption; the roles of envy and altruism on this behaviour are taken limited attention. And in the related literature in Turkey, since there are not seen studies focusing on mentioned relationships, it is hoped that this research would contribute to decrease the relevant gap in literature by testing this hypothesis on a Turkish sample.

\section{Field Research}

\subsection{Purpose, Importance and Method}

The purpose of this research is to understand the possible effects of envy and altruism on conspicuous consumption. Although the feeling of envy has been taken attention in marketing science, it seems that there are few studies that examine its reflections on consumer behaviour. Even the measuring approaches about the envy are new; understanding the effects of different dimensions of envy on certain consumer behaviour would increase our knowledge about consumer behaviour.

In the measurement of the research variables, the 5-point Likert-style measurement tools constructed depending on the studies about the subject. To measure the sense of envy, the BeMaS scale, developed by Lange \& Crusius (2015) and whose validity and reliability in Turkey was tested by Cirpan \& Özdoğru (2017) was used to reveal the benign and malicious dimensions of the envy. Scale items were included in the research questionnaire as in the Turkish validity study. To measure conspicuous oriented consumption, Chaudhuri et al.'s (2011) scale was used, whose validity is supported in many studies, was translated into Turkish. In order to determine the altruism levels of the research participants, the expressions in Stern et al. (1993) and Morgan \& Miller's (2002) researches were adapted to the research.

\subsection{Analysis}

Through the questionnaire prepared, primary data was collected from 373 people between the dates 1-30 October 2019 by the convenience sampling method in the centre of Kirıkkale Province or Turkey. It was determined that $64.5 \%$ of the participants, who answer the related question, were male and their distribution in terms of age was close to each other. The demographic characteristics of the sample group are as follows: 
Table: 1

Demographic Features

\begin{tabular}{|l|c|c|}
\hline \multicolumn{2}{|c|}{ Quantity } & \multicolumn{1}{|c|}{ Valid Percent } \\
\hline Gender & 112 & 35,2 \\
\hline Female & 205 & 64,5 \\
\hline Male & \multicolumn{2}{|c|}{18,6} \\
\hline Age & 67 & 16,7 \\
\hline $20-27$ & 60 & 24,4 \\
\hline $28-35$ & 88 & 26,4 \\
\hline $36-43$ & 95 & 13,9 \\
\hline $44-50$ & 50 & 12 \\
\hline 51 and above & \multicolumn{3}{|}{} \\
\hline Education & 43 & 27,9 \\
\hline Primary School & 100 & 25,4 \\
\hline High School & 91 & 29,6 \\
\hline Associate & 106 & 5 \\
\hline Undergraduate & 18 & \\
\hline Graduate and above & \multicolumn{2}{|c|}{} \\
\hline
\end{tabular}

In order to test the suitability of the data for analysis, the values of kurtosis and skewness are calculated. The values between +- 1,5 allows that the data fit the normal distribution (Tabachnik \& Fidell, 2013). Accordingly, the kurtosis values of the items in the questionnaire were found to vary between -1.26 and 0.08 , and the skewness values ranged from -0.93 to 0.33 , and the data were assumed to be normally distributed.

In research method literature, to evaluate the model fit; it is understood that CMIN/DF (chi-square/ degree of freedom) with value of lower than 3 or 5, the fit value can be assumed as good or acceptable, respectively. Furthermore, RMSEA value of lower than 0,05 , shows the good fit value and the value of lower than 0,08 , show the acceptable fit level of measurement model. Moreover, CFI (comparative fit index) and GFI (goodness of fit index) value above 0.90 indicates that it is acceptable and value above 0.95 indicates that it has a good fit level (Tabachnick \& Fidell, 2012; Kline, 2015; Meydan \& Şeşen, 2011). Accordingly, validity of the research variables was evaluated by confirmatory factor analysis and mentioned goodness of fit values. The resulting goodness of fit values show that the measurement tools used to determine the variables are structurally appropriate as seen in Table 2.

Table: 2

\section{Goodness of Fit Indices}

\begin{tabular}{|c|c|c|c|c|}
\hline & Malicious Envy & Benign Envy & Conspicuous Consumption & Altruism \\
\hline CMIN/DF & 3,337 & 1,866 & 2,824 & 3,031 \\
\hline RMSEA & 0,079 & 0,048 & 0,070 & 0,071 \\
\hline CFI & 0,996 & 0,996 & 0,978 & 0,981 \\
\hline GFI & 0,993 & 0,994 & 0,929 & 0,978 \\
\hline
\end{tabular}

\subsection{Testing the Hypotheses}

Structural equation models were tested to analyse the research hypotheses. First, the model was found as significant according to the structural equation analysis performed to examine the effect of malicious envy on conspicuous consumption. It is seen that goodness of fit values of the model are sufficient, namely CMIN / DF $=2,302$, GFI $=0,945, \mathrm{CFI}=$ 0,974 and RMSEA $=0,059$. The standardized beta coefficient showing the effect of the 
independent variable on the dependent variable was found to be 0.85 . Therefore, the hypothesis " $\mathrm{H}_{1}$ : Malicious envy affects conspicuous consumption" is supported.

Likewise, the goodness of fit values of the model designed to examine the effect of the benign envy on the conspicuous consumption are depicted as sufficient also respectively $\mathrm{CMIN} / \mathrm{DF}=3.157$, GFI $=0.926, \mathrm{CFI}=0.942$ and $\mathrm{RMSEA}=0.076$. According to the results of the analysis, the standardized beta coefficient was determined as 0.39 . So, the hypothesis of " $\mathrm{H}_{2}$ : Benign envy affects conspicuous consumption" is supported.

The structural equation model established to test the effect of altruism on conspicuous consumption was also found meaningful. Goodness of fit values of this model are depicted as; $\mathrm{CMIN} / \mathrm{DF}=2,034, \mathrm{GFI}=0,945, \mathrm{CFI}=0,968$ and $\mathrm{RMSEA}=0,053$. According to the results of the analysis, the standardized beta coefficient was determined to be -0.16 . Accordingly, the hypothesis " $\mathrm{H}_{3}$ : Altruism affects conspicuous consumption" is supported. In short, it is understood that altruism negatively affects conspicuous consumption as expected.

In addition to these, goodness of fit values in the first model developed to examine the moderating role of altruism in the effect of malicious envy on conspicuous consumption; $\mathrm{CMIN} / \mathrm{DF}=1.899, \mathrm{GFI}=0.928, \mathrm{CFI}=0.967$ and $\mathrm{RMSEA}=0.049$. In this model, while malicious envy affects conspicuous consumption, altruism does not affect it. In short, altruism becomes an insignificant variable when it is added to model with malicious envy.

In the model developed to examine the moderating role of altruism in the impact of malicious envy on conspicuous consumption, when the interaction term of altruism and malicious envy was added to the previous model; goodness of fit values of the model; CMIN / $\mathrm{DF}=2,012 \mathrm{GFI}=0,920, \mathrm{CFI}=0,959$ and $\mathrm{RMSEA}=0,052$. In this model, it can be seen that the interaction term significantly affects conspicuous consumption (the standardized beta coefficient of interaction term is 0,14 ) or altruism plays a moderating role in the effect of malicious envy on conspicuous consumption. Hence, the hypothesis " $\mathrm{H}_{4}$ : Altruism plays moderating role in the effect of malicious envy on conspicuous consumption" is supported. The figure1. shows the moderating effect of altruism. Accordingly, it is seen that when malicious envy is high and altruism is low, conspicuous consumption is low, and when malicious envy is low and altruism level is high, conspicuous consumption is low. These means the increase of altruism decreases the effect of envy on conspicuous consumption as seen in the figure. 


\section{Figure: 1}

Moderating Role of Altruism

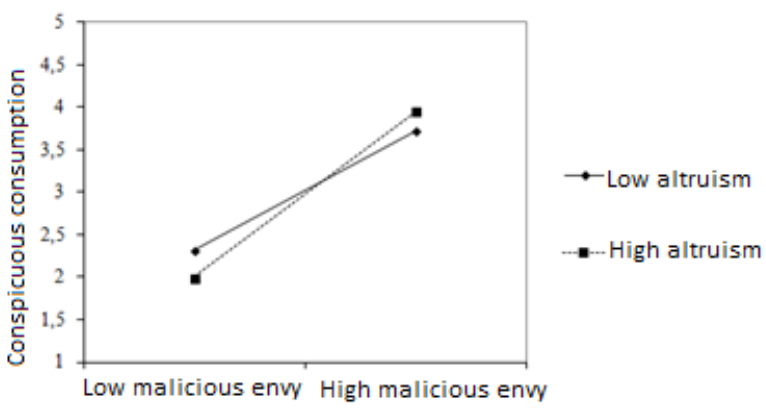

In addition, goodness of fit values of the structural equation model designed to examine the joint effect of altruism and benign envy on conspicuous consumption; CMIN / $\mathrm{DF}=2.482, \mathrm{GFI}=0.909, \mathrm{CFI}=0.932$ and $\mathrm{RMSEA}=0.063$. According to the results of analysis, altruism affects conspicuous consumption negatively and benign envy positively. Therefore, it is understood that altruism, which is insignificant in terms of its effect on conspicuous consumption in the case of malicious envy, plays an important role that reduces the conspicuous consumption in the case of benign envy.

Moreover, where the interaction variable, expressed as the product of the standardized values of altruism and benign envy is added to the model, the interaction term did not affect conspicuous consumption. This shows that altruism does not play a moderating role in the effect of benign envy on conspicuous consumption. Fit values of the relevant model; $\mathrm{CMIN} / \mathrm{DF}=2,377, \mathrm{GFI}=0,908, \mathrm{CFI}=0,930$ and $\mathrm{RMSEA}=0,061$. As a result, the hypothesis " $\mathrm{H}_{5}$ : Altruism plays a moderating role in the effect of benign envy on conspicuous consumption" was not supported.

\subsection{Evaluation}

The results obtained that the malicious envy affects the conspicuous consumption are similar to the researches in the marketing literature (Wong \& Ahuvia, 1998; Le, 2015; Taylor \& Strutton, 2016). However, the results are different from Belk (2008) and Ahn et al.'s (2018) studies, which focusing on the effect of benign envy on conspicuous consumption. This situation is interpreted as the effects of dimensions of envy on conspicuous consumption may differ depending on the sample researched. In terms of the Kirikkale sample, it is understood that malicious envy, which is consist of components such as feeling bad about the superiority of others, is a more important variable in explaining conspicuous consumption than benign envy, which is consist of components like willing to reach the superiority of others.

Another conclusion reached in the research is that altruism reduces the conspicuous consumption. This result is indirectly similar with the studies which demonstrate altruism affects the use of consumption for the benefit of others (society, environment, acquaintance, 
etc.), (Yadav, 2016; Simunaniemi et al., 2013; Lord \& Rangazas 1991; Luo et al., 2007; Lamberton, 2016; Hartl et al., 2016; Bucher et al., 2016). In addition to these, it was determined in this research that although altruism does not play a moderating role in the effect of benign envy on conspicuous consumption, it plays a moderating role in the effect of malicious envy on conspicuous consumption. At this point, when malicious envy is low, high altruism decreases conspicuous consumption, and when the malicious envy is high, the low level of altruism decreases the conspicuous consumption.

\section{Conclusion}

In this research, which was based on the main idea that consumption behaviours can be affected by envy which is a kind of emotion and altruism level of individual; the claims that envy and altruism affect the conspicuous consumption are supported by a field research. In the research, it has been determined that especially malicious envy has a high impact on the conspicuous consumption. Contrary to the conclusions reached in previous studies on the subject, it is understood that feeling negative toward superior others, is a more important factor to motivate behaving conspicuous consumption in researched sample, in which people can be thought as more altruistic and collaborative cultural characteristics compared to the individualistic western societies. This result can be remarkable in terms of designing the marketing communication messages to encourage conspicuous consumption and realizing that the importance of reasons for conspicuous consumption can differ in different cultures. According to this, as can be seen in the studies conducted in western cultures that usually emphasize individualism and self, messages such as "you can be successful like others,... you can succeed,... there is no reason for you not to have it", while in the market environment where the present research is conducted messages like "... you also deserve, ...they are not better than you", can be expected to be more effective. In this context, testing the relative effectiveness of such messages in motivating conspicuous consumption will contribute to understanding the issue.

The conclusion reached in the research that altruism can play an important role in conspicuous consumption is also remarkable. Especially when there is benign envy in the consumer, altruism reduces the conspicuous consumption, and in case of malicious envy, it plays a moderating role. These results show that, with the motivation to reach the superiority of others (benign envy), the high level of altruism will reduce the conspicuous consumption. On the other hand, it is understood that altruism does not affect the conspicuous consumption directly in the malicious envy situation, but it moderates the effect of malicious envy on conspicuous consumption. Accordingly, when malicious envy is low, low altruism increases the conspicuous consumption. These results show that in certain situations (high malicious envy), altruism may not be an obstacle for conspicuous consumption.

The main constraints of this research are that it is carried out with a survey method and in a narrow geographical location, which leads to the fact that the absolute accuracy of the research cannot be guaranteed, and the findings cannot be generalized. On the other hand, descriptive survey method is widely used in social sciences to test certain claims on issues pertaining to consumer perception, emotion, attitude, and behaviours. In addition, it is 
possible by the research to provide valuable information about the relationships between conspicuous consumption, envy, and altruism, and has the potential to give ideas in terms of models, methods and variables to researchers that can be carried out in a larger sample.

\section{References}

Ackerman, D. \& L. Perner (2004), "Did you hear what my friend paid! Examining the consequences of social comparisons of prices", Advances in Consumer Research, 31, 586-593.

Ahn, S. \& Y. Shin \& J.S. Lee \& A.R. Koh (2018), "Green with envy at your kid: The Effects of two different types of envy on purchase intention", International Textile and Apparel Association, ITAA Proceedings, 1-2.

Amaldoss, W. \& S. Jain (2005), "Conspicuous consumption and sophisticated thinking”, Management Science, 51(10), 1449-1466.

Awanis, S. \& B.B. Schlegelmilch \& C.C. Cui (2017), “Asia’s materialists: Reconciling collectivism and materialism”, Journal of International Business Studies, 48(8), 964-991.

Balikcioglu, B. \& P. Volkan (2016), "The Impact of social media, television, and peer communication on materialism and conspicuous consumption", Mustafa Kemal University Journal of Social Sciences Institute, 13(35), 299-319.

Becker, G.S. (1976), “Altruism, egoism, and genetic fitness: Economics and sociobiology”, Journal of Economic Literature, 14(3), 817-826.

Belk, R. (2011), "Benign envy”, AMS Review, 1(3-4), 117-134.

Belk, R.W. (1984), "Three scales to measure constructs related to materialism: Reliability, validity, and relationships to measures of happiness", Advances in Consumer Research, 11, 291297.

Belk, R.W. (1985), "Materialism: Trait aspects of living in the material world", Journal of Consumer Research, 12(December), 265-80.

Belk, R.W. (2008), "Envy and marketing, Envy: theory and research", Oxford: Oxford University Press, 211-226.

Browne, B.A. \& D.O. Kaldenberg (1997), "Conceptualizing self-monitoring: Links to materialism and product involvement", Journal of Consumer Marketing, 14(1), 31-44.

Bucher, E. \& C. Fieseler \& C. Lutz (2016), "What's mine is yours (for a nominal fee)-Exploring the spectrum of utilitarian to altruistic motives for Internet-mediated sharing", Computers in Human Behavior, 62, 316-326.

Chaudhuri, H.R. \& S. Mazumdar \& A. Ghoshal (2011), "Conspicuous consumption orientation: Conceptualisation, scale development and validation", Journal of Consumer Behavior, 10, 216-224.

Christen, M. \& R. Morgan (2005), "Keeping up with the Joneses: Analyzing the effect of income inequality on consumer borrowing", Quantitative Marketing and Economics, 3(June), 1473.

Cirpan, Y. \& A.A. Özdoğru (2017), "BeMaSa haset ve gıpta ölçeğinin Türkçe uyarlaması: Dilsel eşdeğerlik, güvenilirlik ve geçerlilik çalışması”, Anatolian Journal of Psychiatry, 18(6), 577-585.

Clark, P.A. (1985), "Individual education application of Adler's personality theory", The Clearing House, 59(1), 35-38. 
Cohen-Charash, Y. (2009), “Episodic envy”, Journal of Applied Social Psychology, 39(9), 21282173.

Crusius, J. \& T. Mussweiler (2012), "When people want what others have: the impulsive side of envious desire", Emotion, 12(1), 142-153.

De Peyrelongue, B. \& O. Masclef \& V. Guillard (2017), "The need to give gratuitously: A relevant concept anchored in Catholic social teaching to envision the consumer behavior", Journal of Business Ethics, 145(4), 739-755.

Fehr, E. \& U. Fischbacher (2003), “The nature of human altruism”, Nature, 425(6960), 785-791.

Feinberg, F.M. \& K. Aradhna \& Z.J. Zhang (2002), "Do we care what others get? A Behaviorist approach to targeted promotions", Journal of Marketing Research, 39(August), 277-291.

Feldman, A. \& A. Kirman (1974), "Fairness and envy", The American Economic Review, 64(6), 9951005.

Ferguson, E.D. (1989), “Adler's motivational theory: An historical perspective on belonging and the fundamental human striving", Individual Psychology, 45(3), 354-361.

Fitzmaurice, J. \& C. Comegys (2006), "Materialism and social consumption”, Journal of Marketing Theory and Practice, 14(4), 287-299.

Foster, G.M., et al. (1972), "The anatomy of envy: A study in symbolic behavior and comments and reply", Current Anthropology, 13(2), 165-202.

Fournier, S. \& M.L. Richins (1991), "Some theoretical and popular notions concerning materialism. In To have possessions: A handbook on ownership and property", Journal of Social Behavior and Personality, 6, 403-414.

Gershman, B. (2014), "The two sides of envy”, Journal of Economic Growth,19(4), 407-438.

Hartl, B. \& E. Hofmann \& E. Kirchler (2016), "Do we need rules for "what's mine is yours"? Governance in collaborative consumption communities", Journal of Business Research, 69(8), 2756-2763.

Hofstede, G. \& M. Bond (1984), “Hofstede's culture dimensions: an independent validation using Rokeach's Value Survey”, Journal of Cross-cultural Psychology, 15(4), 417-33.

Horton, R. (1991), "Marketing the concept of becoming a potential organ donor", Journal of Health Care Marketing, 11, 36-45.

Horton, R.L. \& P.J. Horton (1991), “A model of willingness to become a potential organ donor", Social Science and Medicine, 33, 1037-1051.

Kline, R.B. (2015), Principles and practice of structural equation modeling, Guilford publications.

Kopfman, J.E. \& S.W. Smith (1996), "Understanding the audiences of a health communication campaign: A discriminant analysis of potential organ donors based on intent to donate", Journal of Applied Communication, 24, 22-49.

Lamberton, C. (2016), "Collaborative consumption: a goal-based framework", Current Opinion in Psychology, 10, 55-59.

Lange, J. \& J. Crusius (2015), "Dispositional envy revisited: Unraveling the motivational dynamics of benign and malicious envy", Personality and Social Psychology Bulletin, 41(2), 284294.

Lay, J.C. \& C.A. Hoppmann (2015), “Altruism and prosocial behavior”, Encyclopedia of Geropsychology, 1-9. 
Le, H.T. (2015), "The role of envy in customer purchasing choice with a focus on fashion industry", Vaasan Ammattikorkeakoulu, University of Applied Sciences, Vaasa, Finlandiya.

Leibenstein, H. (1950), "Bandwagon, snob and Veblen effects in the theory of consumer demand", Quarterly Journal of Economics, 64(2), 183-207.

Lord, W. \& P. Rangazas (1991), "Savings and wealth in models with altruistic bequests", The American Economic Review, 81(1), 289-296.

Luo, T. \& M. Motani \& V. Srinivasan (2007), “Altruistic cooperation for energy-efficient multichannel MAC protocols", 13th annual ACM international conference on Mobile computing and networking, 322-325.

Mai, N.T.T. \& S.K. Tambyah (2011), “Antecedents and consequences of status consumption among urban Vietnamese consumers", Organizations \& Markets in Emerging Economies, 2(1), 75-98.

Mason, R. (2001), “Conspicuous consumption: A literature review”, European Journal of Marketing, 18(3), 26-39.

Meydan, C.H \& H. Şeşen (2011), Yapısal eşitlik modellemesi AMOS uygulamaları, Ankara: Detay.

Mongoven, A. (2003), "Sharing our body and blood: Organ donation and feminist critiques of sacrifice", Journal of Medicine and Philosophy, 28, 89-114.

Morgan, S. \& J. Miller (2002), "Communicating about gifts of life: The effect of knowledge, attitudes, and altruism on behavior and behavioral intentions regarding organ donation", Journal of Applied Communication Research, 30(2), 163-178.

Morgan-Knapp, C. (2014), “Economic envy”, Journal of Applied Philosophy, 31(2), 113-126.

Mujcic, R. \& P. Frijters (2015), "Conspicuous consumption, conspicuous health, and optimal taxation", Journal of Economic Behavior \& Organization, 111, 59-70.

Mustonen, P. (2007), "Volunteer tourism-Altruism or mere tourism?”, Anatolia, 18(1), 97-115.

O’Cass, A. (2001), "Consumer self-monitoring, materialism and involvement in fashion clothing”, Australasian Marketing Journal, 9, 46-60.

Ordabayeva, N. \& P. Chandon (2010), "Getting ahead of the Joneses: When equality increases conspicuous consumption among bottom-tier consumers", Journal of Consumer Research, 38(1), 27-41.

Page, C. (1992), “A history of conspicuous consumption", Association for Consumer Research, 1, 82-87.

Pancer, E. \& L. Ashworth (2009), "Getting what they deserve: The role of fairness in schadenfreude from another's product failure", ACR Asia-Pacific Advances, 8, 2-3.

Parrott, W.G. \& R.H. Smith (1993), "Distinguishing the experiences of envy and jealousy", Journal of Personality and Social Psychology, 64(6), 906-920.

Piron, F. (2000), "Consumers' perceptions of the country-of-origin effect on purchasing intentions of (in)conspicuous products”, Journal of Consumer Marketing, 17(4), 308-321.

Podoshen, J.S. \& L. Li \& J. Zhang (2011), "Materialism and conspicuous consumption in China: A cross-cultural examination", International Journal of Consumer Studies, 35(1), 17-25.

Podoshen, J.S. \& S.A. Andrzejewski \& J.M. Hunt (2014), "Materialism, conspicuous consumption, and American hip-hop subculture", Journal of International Consumer Marketing, 26(4), 271-283. 
Podoshen, J.S. \& S.A. Andrzejewski (2012), “An examination of the relationships between materialism, conspicuous consumption, impulse buying, and brand loyalty", Journal of Marketing Theory and Practice, 20(3), 319-334.

Posner, E.A. (1997), “Altruism, status, and trust in the law of gifts and gratuitous promises", Wisconsin Law Review, 567- 609.

Richins, M.L. \& S. Dawson (1992), "A Consumer values orientation for materialism and its measurement: Scale development and validation", Journal of Consumer Research, 19(December), 303-316.

Richins, M.L. (1994), "Special possessions and the expression of material values", Journal of Consumer Research, 21(December), 522-533.

Schwartz, S.H. (1977), "Normative influences on altruism", Advances in Experimental Social Psychology, 10, 221-279.

Segal, B. \& J.S. Podoshen (2013), "An examination of materialism, conspicuous consumption and gender differences”, International Journal of Consumer Studies, 37(2), 189-198.

Shaw, R. (2010), "Perceptions of the gift relationship in organ and tissue donation: Views of intensivists and donor and recipient coordinators", Social Science \& Medicine, 70(4), 609-615.

Shon, P.C.H. \& S. Barton-Bellessa (2015), "The assumption of rational choice theory in Alfred Adler's theory of crime: Unraveling and reconciling the contradiction in Adlerian theory through synthesis and critique", Aggression and Violent Behavior, 25, 95-103.

Simunaniemi, A.M. \& H. Sandberg \& A. Andersson \& M. Nydahl (2013), "Normative, authentic, and altruistic fruit and vegetable consumption as weblog discourses", International Journal of Consumer Studies, 37(1), 66-72.

Souiden, N. \& B. M'Saad \& F. Pons (2011), “A cross-cultural analysis of consumers' conspicuous consumption of branded fashion accessories", Journal of International Consumer Marketing, 23(5), 329-343.

Sque, M. \& S. Payne \& C.J. Macleod (2006), “Gift of life or sacrifice?: Key discourses to understanding organ donor families' decision-making”, Mortality, 11(2), 117-132.

Stern, P. \& T. Dietz \& L. Kalof (1993), "Value orientations, gender, and environmental concern", Environment and Behavior, 25, 322-348.

Stevens, E.B. (1948), "Envy and pity in Greek Philosophy", The American Journal of Philology, 69(2), 171-189.

Sun, T. \& M. Horn \& D. Merritt (2004), "Values and lifestyles of individualists and collectivists: a study on Chinese, Japanese, British and US consumers", Journal of Consumer Marketing, 21(5), 318-331.

Tabachnick, B.G. \& L.S. Fidell (2013), Using multivariate statistics, Boston: Pearson.

Tan, K.A. (2019), "The effects of personal susceptibility and social support on Internet addiction: An application of Adler's theory of individual psychology", International Journal of Mental Health and Addiction, 17(4), 806-816.

Taylor, D.G. \& D. Strutton (2016), "Does Facebook usage lead to conspicuous consumption? The role of envy, narcissism and self-promotion”, Journal of Research in Interactive Marketing, 10(3), 231-248. 
Taylor, G. \& J. Wangaruro \& I. Papadopoulos (2012), "It is my turn to give: migrants' perceptions of gift exchange and the maintenance of transnational identity", Journal of Ethnic and Migration Studies, 38(7), 1085-1100.

Teimourpour, B. \& H.K. Heidarzadeh (2011), "The impact of culture on luxury consumption behaviour among Iranian consumers", Journal of Islamic Marketing, 2(3), 309-328.

Thoumrungroje, A. (2014), "The Influence of social media intensity and EWOM on conspicuous consumption", Procedia - Social and Behavioral Sciences, 148, 7-15.

Tosun, N.Z. \& D.K. Cesur (2018), “The Paranormality of consumption: The Relationship between conspicuous consumption and paranormal beliefs", Öneri Journal, 13(49), 167-186.

Triandis, H.C. (1989), "The self and social behaviour in differing cultural contexts", Psychological Review, 96, 506-520.

Trivers, R.L. (1971), "The evolution of reciprocal altruism”, The Quarterly Review of Biology, 46(1), 35-57.

Truong, Y. \& G. Simmons \& R. McColl \& P.J. Kitchen (2008), "Status and conspicuousness-are they related? Strategic marketing implications for luxury brands", Journal of Strategic Marketing, 16(3), 189-203.

Wong, N.Y. \& A.C. Ahuvia (1998), "Personal taste and family face: Luxury consumption in Confucian and Western societies", Psychology \& Marketing, 15(5), 423-441.

Wong, N.Y.C. (1997), "Suppose you own the world and no one knows? Conspicuous consumption materialism and self", Advances in Consumer Research, 24, 197-203.

Yadav, R. (2016), "Altruistic or egoistic: Which value promotes organic food consumption among young consumers? A study in the context of a developing nation", Journal of Retailing and Consumer Services, 33, 92-97.

Zizzo, D.J. (2003), "Money burning and rank egalitarianism with random dictators", Economics Letters, 81, 263-266. 
Bozac1, İ. (2021), "Effect of Envy and Altruism on Conspicuous Consumption Orientation: A Research in Kırıkkale, Turkey”, Sosyoekonomi, 29(48), 75-89. 